\title{
Urban criteria based on the example of the smallest towns in Poland
}

\begin{abstract}
The article attempts to develop a preliminary practical framework for urban criteria in terms of the population, economy and spatial location of the smallest towns in Poland. Despite being of little significance, the fact that they lie near the border between being rural settlements and towns makes them an interesting subject for research and more detailed analysis. The current phenomenon of urban status being obtained by ever-smaller settlements is causing conceptual disorder. Therefore, the article may serve as an early contribution to a discussion about the need to define and unify urban criteria on a national scale. The qualitative and descriptive guidelines contained in official acts are insufficient and too general, which is why quantitative methods were used in the present research. Despite the limited data available, research on the topic of urbanity has proven the imperfection of the Polish administrative system and confirmed the premise that town status may be conferred inappropriately in numerous cases.
\end{abstract}

Keywords

Smallest towns • transitional settlements $\bullet$ urbanity

(C) University of Warsaw - Faculty of Geography and Regional Studies

\author{
Mateusz Cudo \\ Faculty of Geosciences, \\ University of Szczecin, Poland \\ e-mail: mateusz.cudo@wp.pl \\ Received: 15 May 2018 \\ Accepted: 29 October 2018
}

Introduction

There is a lot of inaccuracy and inconsistency in definitions of urbanity between countries. Despite efforts by the United Nations, the OECD and Eurostat to create a methodology that would allow international comparisons, the definition of what is rural or urban varies depending on each country's administrative or functional approach, state of development or own specifics. Forstall and Chan (2015) grouped 40 countries with an urban population of at least 15 million into nine categories by how they distinguish urban units. For instance, in Germany, Italy and Spain they are small administrative units, like urban communes (in Germany they are called Stadtgemeinde), with a population threshold of 10,000 in Italy and Spain. By contrast, Poland, Russia and Ukraine define these as incorporated municipalities that are distinct from non-municipal territory, and in Russia the required population is between 20,000 and 50,000 (Gunko 2014). In Germany, there is also no equivalent of the so-called "dwarf city" category (Zwergstadt or Landstadt), for a class of small towns with fewer than 5,000 residents (Heineberg 2006). In the Czech Republic, according to the latest studies (Vaishar et al. 2016), the lower limit of urbanity is considered to be 3,000 inhabitants. In the United Kingdom urban units are not based on administrative borders but are agglomerations with a certain population $(10,000)$. However, in France, there is a different definition, based on urban continuity in which, according to the Institut National de la Statistique et des Etudes Economiques, "the notion of urban unit is based on the continuity of built up land mass and the number of inhabitants", where buildings are no more than $\mathbf{2 0 0}$ metres apart and the number of residents is at least 2,000 .
In the Polish administrative system, rurality/urbanity is still determined as the lack or possession of formal urban status, which does not correspond to the more complex reality. The Regulation of the Council of Ministers from 9th August 2001 concerning the procedure for submitting applications regarding (...) granting urban status, (...) and the documents required in these matters, specifies that, as an applicant, the Commune Council undertakes to provide a number of documents containing historical background, basic statistical data and the results of consultations with residents. In turn, according to the Act of 8th March 1990 on local self-government, obtaining town status "is carried out in a way that takes into account social and technical infrastructure as well as the urban layout and character of the built-up area". These are still more like guidelines than real criteria because, according to Dymitrow (2012), "guidelines imply which attributes of urbanity (so called 'prerequisites') a settlement must possess in order to obtain formal urban status, but they do not state the level of intensity of these attributes, something that formal criteria would normally do".

The purpose of the research was to develop a preliminary practical framework for urban criteria with regard to the population, economy and spatial location of the smallest towns in Poland. The smallest towns - settlements of up to 2,000 people - have been a subject of interest to Polish geographers (Drobek 2005). According to the latest changes on 1st January 2018, the smallest town in Poland became Wiślica, with a population of 500 people, and the third smallest is Józefów nad Wisła, which is slightly bigger than what was for a long time the smallest town - Wyśmierzyce. For that reason, it is important to reconsider the 
significance of the applicable urban criteria and the legitimacy of administrative decisions. Therefore, the article may serve as an early contribution to the discussion about the need to define and unify the urban criteria on a national scale. It is organised into four main parts. The introduction presents international definitions and characteristics of the level of urbanity across Europe, Polish acts with guidelines determining urban status, the current situation in Poland, and the purpose of the research. The second part describes the quantitative research methods used in the paper, followed, thirdly, by proper analysis of the results, relating to the three main aspects of urbanity - population, economy and spatial location. The last section summarises and discusses the research results.

\section{Methods}

Quantitative research methods based on empirical data were used to characterise the group of the smallest towns, describing different aspects of urbanity - the population, economy and spatial location of the particular centres. In order to cope with the complexity of settlement systems, Coombes (2004) suggests that "attention now moves towards the more operational aspects involved in translating conceptual ideas about identifying and distinguishing settlements into specific measures". The chosen aspects also correspond to Pacione (2009), who distinguished four main methods of identifying urban units: population size, economic base, functional definitions and administrative criteria.

The first quantitative criterion of urbanity - population was examined by determining the statistical limits in terms of the number of residents. This part of the research was based on the procedure proposed by Sokołowski (1998), who studied the dependence of the probability of urbanity on the population size of settlements. This method makes it possible to determine threshold values based on linear regression. In order to achieve this, all seats of administrative districts (gmina) of population between 500 (roughly the population of the smallest town, Wiślica) and 5,500 (the approximate population of the smallest county town, Lesko) were listed, including villages as well as towns. On the basis of existing administrative divisions (as of 1st January 2018) the share of centres with urban status was calculated. The total number of settlements (over 1,500) was divided into 14 equal groups. For each of them, the percentage of towns (y-axis) and the maximum population (x-axis) was calculated. The data came from the Local Data Bank of the Polish Central Statistical Office for towns as at the end of 2016, excluding towns which obtained their status after 2016 and all villages (the results of the last census in 2011).

The second part of the study was aimed at analysing the structure of the economy and defining the potential and functions of particular towns. However, due to the lack of detail about employment structure or gross value added according to the Polish Classification of Activities (PKD 2007), only the number of economic entities was used to determine the local specialisation of towns, with the help of the Florence indicator. According to Szymańska (2009), "Nevertheless, in the absence of other reliable data sets, this statistic is the only one that gives the most reliable presentation of the distribution of business entities in space." The Florence indicator of local specialisation was calculated as a quotient of the percentage share of individual sections in the structure of a town, and a percentage share of the same feature in a hierarchically higher unit (Runge 2006) - all towns and cities. In this way, it was possible to compare the intensity and overrepresentativeness of a given feature in a particular centre.

The last part of the research focused separately on the spatial distribution of the smallest towns and their location in the settlement network in relation to large towns and cities the capitals of counties and voivodeships. With the use of GIS technology, it was possible to explore basic regularities and inequalities in various regions based on the road distances between the administrative centres. According to the division proposed by Warakomska (1992) such transportation accessibility is discussed with regard to the "accessibility of a central place" from a certain settlement. Contrary to more recent studies (e.g. Burdziej 2016) that deal with temporal or economic accessibility, the method applied is related to physical accessibility (Guzik 2014), and according to Komornicki et al. (2008) it is measured by "the very existence of a specific infrastructure, or its expansion, in a given region" and not "the actual time or cost of traveling to the specified places". Similar analysis of the distance between towns and cities in Poland due to their topographic location was done by Kostrubiec (1972), though with the use of the shortest dendrite for neighbouring urban settlements.

\section{Research analysis and results}

According to the Act of 29th August 2003 on official names of localities and physiographic objects, an urban settlement is a "unit with a majority dense development and non-agricultural functions which has municipal rights or the status of town conferred in the procedure stipulated by separate provisions". However, this is not a very precise definition, and is not systematised by other regulations. Studying cases of newly established towns in 20042017 shows that the main criteria which play a decisive role are: the character of the built-up area (lack of farm buildings in the compact built-up area); the prevalence of the population living off non-agricultural activities; and support from residents shown by a majority of votes. As confirmation, all of these guidelines were met by each of the 39 towns newly established in the mentioned period of time.

As of 1st January 2018, there were 65 towns in Poland with a population of up to 2,000 people, five of which do not exceed 1,000 people. Their number differs significantly at the provincial level (Fig. 1), from 12 in Wielkopolskie Voivodeship, to one each in Łódzkie, Pomorskie and Warmińsko-Mazurskie. The location of the examined towns shows some regularities on the national scale: they rarely occur in northern and south-western regions. The two largest clusters, consisting of over 30, are located in south-eastern Poland (the Świętokrzyskie voivodeship and neighbouring parts of the Podkarpackie, Lubelskie and Małopolskie voivodeships) and in southern Wielkopolska (along with nearby parts of the Lubuskie and Łódzkie voivodeships).

The first criterion considered relates to population. According to Szmytkie (2014), among all the aspects of urbanism, population number was the basic component of the definition of a town, and the only one that was included by various authors (Ratzel 1891; Bobek 1927; Sorre 1952; George 1956; Dziewoński 1956; KiełczewskaZaleska 1972; Sokołowski 1999). Some towns continue to function as urban settlements despite the fact that the threshold of 2,000 people is one of the criteria for granting town status (Drobek 2002; Szmytkie \& Krzysztofik 2011; Sokołowski 2014). The analysis of the size of new towns established in the years 1980-2011 showed that, at the time of gaining urban status, over $85 \%$ of them had more than 2,000 inhabitants (Szmytkie \& Krzysztofik 2011). However, this regularity has changed in the last few years, as the share of new towns with fewer than 2,000 inhabitants increased to nearly $50 \%$.

The linear trend discovered during the research (Fig. 2) indicates that the minimum size (above $0 \%$ ), which refers to the least probability of a settlement to become a town, is about 1,111 people. Such a condition is not fulfilled by the five smallest towns - Wiślica, Wyśmierzyce, Józefów nad Wisłą, Działoszyce, and Suraż. According to the size criterion, a settlement might become a fully-fledged town when its population reaches approximately 4,884 people. There were 45 seats of administrative districts (gmina) in the studied group (of up to 5,500 people), that fulfil 


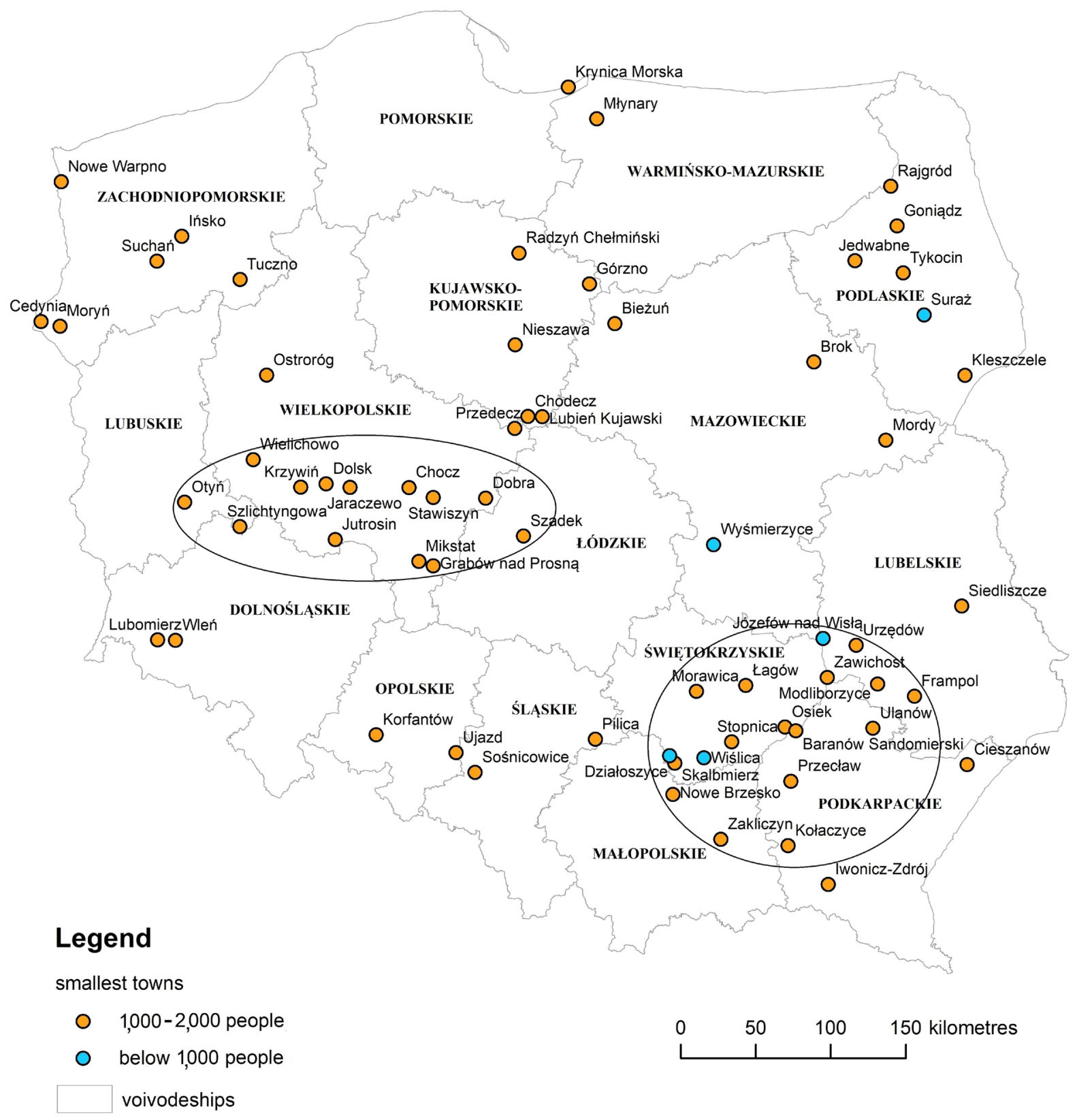

Figure 1. Location and distribution of the smallest towns in Poland (as at 01.01.2018) with the two main clusters marked. Source: own elaboration

this condition, including 21 villages, predominantly in the south of Poland. This confirms the phenomenon of regional diversity pointed out by Sokołowski (1998). According to him, the average size of settlement units in the region ("settlement background") significantly influences the relative size of a particular settlement.

The values of the groups of biggest centres that deviated from the observed upward trend, which is caused by the large number of villages (seats of administrative districts) of over 3,000 people in the south of Poland, were treated as outliers and not included. The group of smallest settlements, which formed the bottom part of the graph, adjacent to the $\mathrm{x}$-axis and close to $0 \%$, was treated similarly, Therefore, the results are inaccurately estimated. The fact, however, that among the studied settlements, 21 villages (seats of administrative districts), reach the estimated limit of $100 \%$, and five towns do not exceed $0 \%$, raises the question of the validity of the applicable administrative division of the country.

In the next part of the study the values of the Florence indicator were calculated. Those above 10, meaning strong specialisation, occurred in 14 towns (Table 1). Among them, three were characterised by a strong intensity of two types of dominating sections (mixed type). In addition to agricultural activity, Radzyń Chełmiński was distinguished by specialisation in electricity generation and supply, which results from the development of renewable energy generation in the commune in the form of wind farms. Elsehwere, as a seaside resort, in addition to fishing, Krynica Morska has a dominant section 


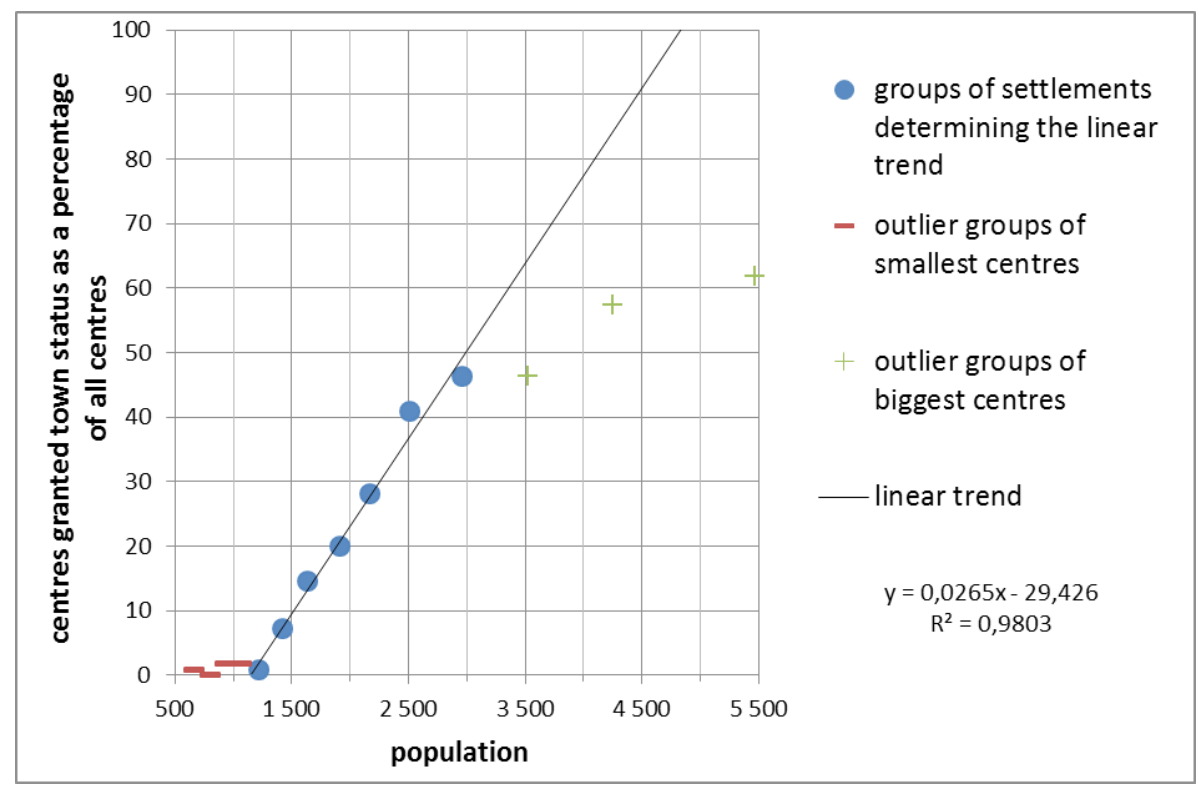

Figure 2. The relationship between population size and the urban status of seats of administrative districts (gmina) in Poland. Source: own elaboration with the use of Local Data Bank.

Table 1. Types of specialisation in the structure of the economy of the smallest towns in Poland in 2016

\begin{tabular}{|c|c|c|c|c|c|}
\hline \multicolumn{3}{|c|}{ Strong specialisation } & \multicolumn{3}{|c|}{ Medium specialisation } \\
\hline Town & $\begin{array}{l}\text { Dominant section } \\
\text { (PKD 2007) }\end{array}$ & Florence indicator & Town & $\begin{array}{l}\text { Dominant section } \\
\text { (PKD 2007) }\end{array}$ & $\begin{array}{l}\text { Florence } \\
\text { indicator }\end{array}$ \\
\hline Bieżuń & A & 29.99 & Górzno & $\mathrm{D} / \mathrm{A}$ & $9.87 / 8.24$ \\
\hline Radzyń Chełmiński & $\mathrm{D} / \mathrm{A}$ & $26.36 / 21.00$ & Jutrosin & B & 9.84 \\
\hline Krynica Morska & $\mathrm{I} / \mathrm{A}$ & $16.92 / 11.78$ & Działoszyce & $\mathrm{O}$ & 9.62 \\
\hline Krzywiń & A & 14.02 & Kołaczyce & $\mathrm{O}$ & 9.62 \\
\hline Suraż & $\mathrm{O}$ & 13.02 & Szadek & $\mathrm{D}$ & 9.55 \\
\hline Otyń & A & 12.90 & Bieżuń & $E$ & 9.22 \\
\hline Wiślica & $\mathrm{O}$ & 11.83 & $\begin{array}{l}\text { Józefów nad } \\
\text { Wisłą }\end{array}$ & $\mathrm{O}$ & 9.11 \\
\hline Kleszczele & $\mathrm{A} / \mathrm{O}$ & 11.29/11.18 & Wielichowo & A & 9.05 \\
\hline Jaraczewo & $\mathrm{O}$ & 10.89 & Mordy & $\mathrm{A} / \mathrm{O}$ & $8.73 / 7.57$ \\
\hline Wyśmierzyce & $\mathrm{O}$ & 10.72 & Nowe Warpno & A & 8.60 \\
\hline Goniądz & $\mathrm{D}$ & 10.64 & Moryń & $\mathrm{A}$ & 8.43 \\
\hline Szlichtyngowa & $\mathrm{O}$ & 10.61 & Rajgród & $\mathrm{A} / \mathrm{O}$ & 7.99/7.91 \\
\hline Cieszanów & $\mathrm{E}$ & 10.19 & Ulanów & $\mathrm{O}$ & 7.91 \\
\hline Siedliszcze & $\mathrm{O}$ & 10.09 & Dobra & $\mathrm{O}$ & 7.74 \\
\hline
\end{tabular}

where: A - Agriculture, forestry, hunting, fishing; B - Mining, quarrying; D - Electricity, gas, steam, hot water, air conditioning manufacturing and supply; $E$ - Water supply, sewerage, waste management, remediation activities; I - Accommodation, food service activities; O - Public administration, defence, compulsory social security. Source: own study based on Local Data Bank.

associated with accommodation and food service activities. Average specialisation (values between 7.5 and 10) was also noted in 14 centres. One of them - Bieżuń, with a strong specialisation in agriculture (a value around 30 ) - also had an average specialisation in activities related to the collection, treatment and disposal of waste (a value around 9). To sum up, the strong and average specialisation that occurred in the studied towns was mostly related to section A (12 centres) and section $O$ (14 centres). The overrepresentativeness of these types of entity in the structure of the economy of the smallest towns proves their insufficient industrial and services development, as well as the expansion of public administration.

The development of small towns is strongly dependent on their place in the settlement network (Koźlak 2012). Their location 


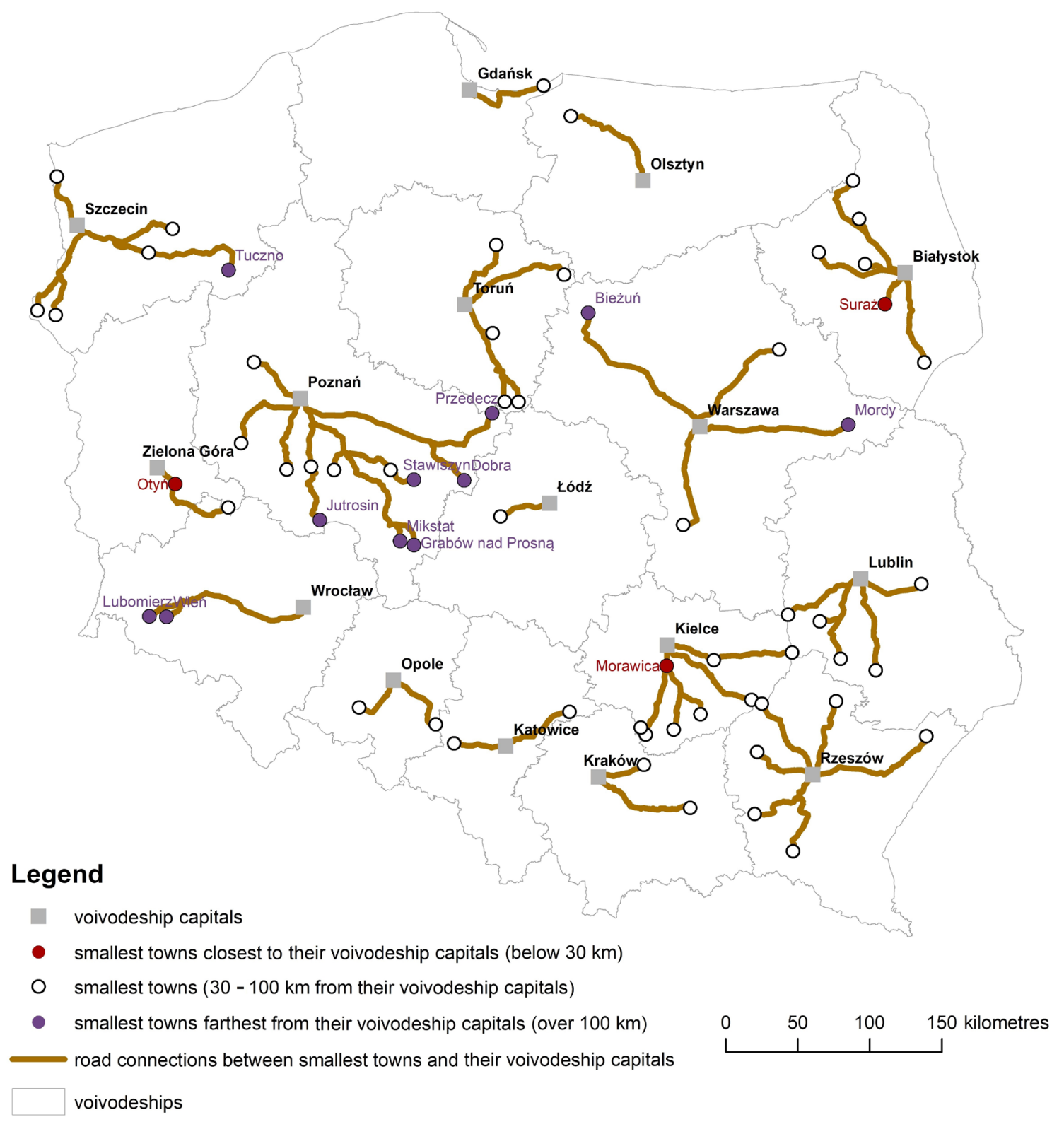

Figure 3. Road connections between smallest towns and their voivodeship capitals in Poland. Source: own elaboration with the use of GIS.

in relation to large agglomerations - centres of socio-economic activities and places of spreading innovations - diversifies their possibilities for development and importance in regional arrangements (Konecka-Szydłowska 2016). According to Koźlak (2012), transport accessibility "is one of the key concepts in development planning of urban settlements and regions", which, in geographic terms, "is closely related to the spatial distance that must be overcome to move from one place to another". Therefore, the smallest towns, as lower-level units in the country's settlement hierarchy, have been examined in terms of their spatial distribution and road connections with higher-level units - the capitals of counties (powiat) and voivodeships.

The average road distances to the studied towns indicate that they are located close to the seats of their counties (about $20 \mathrm{~km}$ ) and relatively far from voivodeship capitals (about $74 \mathrm{~km}$ ). However, taking into consideration the different specificities, some voivodeships can be characterised by a relatively smaller area or latitudinal extent, such as the Opolskie and Śląskie Voivodeships. The distances from the 57 smallest towns to their county capitals are mainly between 10 and $30 \mathrm{~km}$. There are some examples that stand out in this regard: Otyń (Lubuskie Voivodeship) is only $5 \mathrm{~km}$ from Nowa Sól, and Moryń and Cedynia (West Pomeranian Voivodeship) are over $50 \mathrm{~km}$ from Gryfino.

Analysis of the location of the smallest towns in the interregional cross-section showed a significant relationship between the rank of capitals of voivodeships and the distance between them and the smallest towns by road (Fig. 3). Most of them have a peripheral location relative to voivodeship capitals, and they are usually close to voivodeship borders. One example is Podkarpackie Voivodeship, where such towns are distributed radially, adjacent to the border of the province and peripherally to the capital, contrary to Podlaskie, where the smallest towns are located in a north-south direction in closer proximity (Suraż, Tykocin) to the capital. Potentially, this may prove to be of greater 
importance in shaping the settlement network of Rzeszów, which, unlike Białystok, has influenced a spatial urban hierarchy in the region. It also confirms that the voivodeship category, which structurally creates a node-shaped settlement system with a main centre, is more than just a unit of administrative division (Jażewicz 2016).

Among the studied centres, the four located farthest from their voivodeship capital are in Wielkopolskie Voivodeship Przedecz, Grabów nad Prosną, Mikstat and Dobra. Moreover, road distances above $100 \mathrm{~km}$ also occurred in Zachodniopomorskie (one town), Dolnośląskie (two), Mazowieckie (two), and again in Wielkopolskie (two). Apart from the city of Szczecin, all the capitals of the mentioned voivodeships are considered to be the most important centres of metropolitan areas in Poland (Markowski \& Marszał 2006), being national growth poles. At only ten to twenty kilometres away, the centres closest to the voivodeship cities are Morawica (Świętokrzyskie) and Otyń (Lubuskie). These centres obtained their municipal status in 2017 and 2018 respectively, which may prove the imperfection of the administrative decisions granting urban status in Poland. On the other hand, it confirms the weakness of both voivodeship capitals, namely Kielce and Zielona Góra, which, within their suburban zones, were unable to promote these settlements to higher size categories.

\section{Summary and discussion}

The article examines the three main apects of urbanity and, once developed on the basis of more detailed and recent data, each could be the topic of its own separate article. The purpose of the research was to look at the phenomenon of urbanity from different angles, in order to discover the basic regularities in terms of population, economy and the spatial aspect. It does not exclude, however, the significance of other urban features, which may be even more quantitatively described. In fact, the emergence of new towns could also be identified by the increased diffusion of the "idea of institutionalisation" and the "idea of selfempowerment" (Szmytkie \& Krzysztofik 2011), which, although they do not guarantee tangible benefits, are often considered as opportunities for more dynamic development. These tendencies are clearly visible in the case of Lubelskie and Świętokrzyskie Voivodeships, where, in the last five years, six and five villages, respectively, have changed their status from village to town. Among them, eight were settlements with a population below 2,000 people: Józefów nad Wisłą, Modliborzyce, Siedliszcze, Urzędów (Lubelskie) and Łagów, Morawica, Stopnica, Wiślica (Świętokrzyskie).

On the basis of the research conducted, regarding the size criterion, "quasi-urban", "quasi-rural" settlements have between 1,111 and 4,884 inhabitants, and once reaching the latter number, statistically should become a fully-fledged town. In this way, it should be considered whether towns and villages (seats of administrative districts [gmina]) included in-between the mentioned values, should have a separate category as transitional units. Transitional settlements were distinguished by KiełczewskaZaleska (1972) as "those which have, apart from the agricultural function, another one-sidedly developed service, housing or production function" and "generally small, in which there was no development and concentration of the multidimensional aspects of urban settlements, but which have already adopted certain sectors of the non-agricultural economy and have a different character than the ordinary agricultural village". A seperate group of such settlements under the name of "urbanised unit" and "semi-town" was also proposed by Sokołowski (1999). Perhaps it would be reasonable to re-establish the category of urban-type settlements (osiedle typu miejskiego), which was valid between 1954 and 1973 in Poland, or another one called the "small-town" (miasteczko), introduced by the Austrian authorities in the former Galicia in the 19th century (Karpiniec 1932; Jelonek 1967).

In economic terms, the smallest towns function as centres of only local significance; they do not play the role of supralocal growth poles, as they only generate an impact within the range of their municipalities. They are particularly affected by problems of social and economic stagnation; despite infrastructural investments and local initiatives they are not competitive enough to attract investors and their capital in order to set up more innovative types of economic activities. The structure of their local economies is based on small trade and services, the food industry, construction and wood processing. These activities are only a consequence of the concentration of people in a town, and not the reason for its existence (Kuciński 2004). In comparison with other Polish towns and cities, they are mostly "specialised" in agriculture and public administration. They often require external intervention in order to unify the strategy of their development and strengthen the processes of urban activation, which was already the subject of geographic research in the 1950s (Dziewoński et al. 1957).

Because of the fact that they have not been promoted to upper size categories, these are towns of low attractiveness to settle in, which may result from their peripheral location with regard to agglomerations or major roads and railways. Their limited transport accessibility causes economic stagnation and leads to adverse social phenomena, such as the outflow of young and educated people. There are also examples of close proximity between the smallest towns and their county seats (as in the case of Nowa Sól) or their voivodeship capitals (Kielce, Białystok), which therefore brings into question the urban status of those settlements.

Some researchers (Stanny et al. 2016) claim that "the methodological dilemma concerning the determination of the relations between a town and a village, is ultimately undecidable". According to Dymitrow, (2012) "the process of designating urbanity in Poland is accompanied by several intricacies and inconsistencies (...) that could seem detached from a rational urbanisation process". In such situations, there is a conceptual chaos, as town privileges are obtained by ever-smaller settlements, which, in the absence of the degradation of urban status, results in a constantly growing number of new towns in Poland. This process may continue, because, according to Krzysztofik (2008), the number of urbanised villages in Poland certainly exceeds the number of existing towns. Therefore, the quantification of urbanity becomes an important task for settlement or urban geography, and once certain solutions and practical applications can be provided, it may also contribute to the prestige of these disciplines.

\section{References}

Bobek, H 1927, 'Grundfragen der stadtgeographie', Geographischer Anzeiger, vol. 28, pp. 213-224.

Burdziej, J 2016, 'Analiza dostępności przestrzennej za pomocą technologii GIS na przykładzie obiektów użyteczności publicznej w Toruniu' [Analysis of spatial accessibility using GIS technology on the example of public buildings in Torun], Prace KGK PTG [Transport Geography Papers of Polish Geographical Society], vol. 19, no. 1, pp. 43-51.
Coombes, M 2004, 'Multiple dimensions of settlement systems: coping with complexity', in New Forms of Urbanization. Beyond the urban-rural dichotomy, eds T Champion \& G Hugo, Ashgate Publishing Limited, Aldershot, pp. 307324.

Drobek, W 2002, 'Polskie nowe miasta (1977-2001)' [Polish new towns in the years 1977-2001] in Przemiany bazy ekonomicznej $i$ struktury przestrzennej miasta 
[Transformations of the economic basis and spatial structure of cities], ed J Słodczyk, Wydawnictwo Uniwersytetu Opolskiego, pp. 71- 84 .

Drobek, W 2005, 'Najmniejsze miasta w Polsce (1989-2003)' [The smallest towns in Poland (1989-2003)] in Małe miasta a rozwój lokalny i regionalny [Small towns - local and regional development], ed K Heffner, Wydawnictwo Akademii Ekonomicznej, Katowice, pp. 53- 58.

Dymitrow, M 2012, 'The hidden face of urbanity. Morphological differentiation of degraded and restituted towns in Poland in the context of the efficacy of the National Administrative System', Göteborg University, Göteborg.

Dziewoński, K 1956, 'Geografia osadnictwa i zaludnienia. Dorobek, podstawy teoretyczne i problemy badawcze' [The settlement and population geography. Achievement, theoretical basis and research problems], Przegląd Geograficzny [Polish Geographical Review], vol. 28, no. 4, pp. 721-764.

Dziewoński, K, Kiełczewska-Zaleska, M, Kosiński, L, Kostrowicki, J \& Leszczycki S 1957, 'Studia geograficzne nad aktywizacją małych miast' [Geographical studies of development of small towns], Prace Geograficzne [Geographical Studies], vol. 9, IG PAN, Warszawa, pp. 21-52.

Forstall, RL \& Chan, KW 2015, 'Urban places: statistical definitions' in International Encyclopedia of the Social and Behavioral Sciences, ed J Wright, 2nd ed., Elsevier, Amsterdam, pp. 854-861.

George, P 1956, Miasto [City], PWN, Warszawa.

Gunko, MS 2014, 'Small towns in the central part of European Russia. Socioeconomic state and the role in organizing territory', Regional Research of Russia, vol. 4, no. 4, pp. 231-239.

Guzik, R 2014, Dostępność transportowa wybranych miast Małopolski 2014-2023 [Transport accessibility of selected cities in Malopolska 2014-2023], Małopolskie Obserwatorium Rozwoju Regionalnego, Kraków.

Heineberg, H 2006, Stadtgeographie, Schöningh, Paderborn.

Jażewicz, I 2016, 'Miejska sieć osadnicza projektowanego województwa środkowopomorskiego' [Urban settlement network in designed Środkowopomorskie voivodeship], Zeszyty Naukowe Wydziału Nauk Ekonomicznych Politechniki Koszalińskiej [Research Bulletins of the Faculty of Economic Sciences of the Koszalin University of Technology], vol. 20, no. 2, pp. 57-76.

Jelonek, A 1967, 'Ludność miast i osiedli typu miejskiego na ziemiach Polski od 1810 do 1960 r.' [The population of cities and urban settlements on the territory of Poland, 1810-1960], Dokumentacja Geograficzna [Geographical Documentation], vol. 3/4, IG PAN, Warszawa.

Karpiniec, J 1932, 'llość osad miejskich byłej Galicji i podział ich na miasta i miasteczka' [The number of urban settlements of the former Galicia and their division into cities and towns] in Roczniki Dziejów Społecznych i Gospodarczych [Social and Economic History Annals], eds F Bujak, J Rutkowski, Lwów.

Kiełczewska-Zaleska, M 1972, Geografia osadnictwa [Settlement Geography], PWN, Warszawa.

Komornicki, T, Śleszyński, P, Pomianowski, W, Rosik, P, Siłka, P \& Stępniak M 2008, Opracowanie metodologii liczenia wskaźnika międzygałęziowej dostępności transportowej terytorium Polski oraz jego oszacowanie [Preparation of the methodology for calculating the rate of inter-branch transportation accessibility of Poland and its estimation], Instytut Geografii i Przestrzennego Zagospodarowania PAN, Warszawa
Konecka-Szydłowska, B 2016, 'Powiązania społecznogospodarcze i znaczenie małych miast aglomeracji poznańskiej' [Socio-economic links and significance of small towns of the Poznań agglomeration], Studia Ekonomiczne. Zeszyty Naukowe Uniwersytetu Ekonomicznego w Katowicach [Economic studies. Research Bulletins of the University of Economics in Katowice], vol. 279, pp. 162-177.

Kostrubiec, B 1972, 'Analiza zjawisk koncentracji w sieci osadniczej - problemy metodyczne' [Analysis of concentration phenomena in settlement network methodical issues], Prace Geograficzne, vol. 93, IG PAN, Warszawa.

Koźlak, A 2012, 'Zróżnicowanie dostępności transportowej małych miast w Polsce na przykładzie miast powiatowych' [Differences in the transport accessibility of small towns in Poland on the example of capitals of poviats] in Ewolucja funkcji małych miast $w$ Polsce [The evolution of the functions of small towns in Poland], eds $\mathrm{K}$ Heffner \& A Halama, Studia Ekonomiczne. Zeszyty Naukowe Uniwersytetu Ekonomicznego w Katowicach, vol. 92, pp. 148-162.

Kuciński, K 2004, Geografia ekonomiczna. Zarys teoretyczny [Economic geography. A theoretical outline], Oficyna Wydawnicza SGH, Warszawa.

Krzysztofik, R 2008, 'Osiedla zurbanizowane bez formalnego statusu miejskiego na obszarze Polski w rozwoju historycznym - próba typologii' [Urbanized settlements without formal urban status in the area of Poland according to historical development - attempt of typology] in Problemy $i$ metody oceny kontinuum miejsko-wiejskiego w Polsce [Evaluation of the rural-urban continuum in Poland problems and methods], eds W Gierańczyk \& M Kluba, Studia Obszarów Wiejskich, vol. 13, Warszawa, pp. 185193.

Local Data Bank, n.d. Available from: <http://bdl.stat.gov.pl>. [30 April 2018]

Markowski, T \& Marszał, T 2006, Metropolie, obszary metropolitalne, metropolizacja. Problemy i pojęcia podstawowe [Metropolises, metropolitan areas, metropolitalisation. Problems and basic terms], Komitet Przestrzennego Zagospodarowania Kraju PAN, Warszawa.

Pacione, M 2009, Urban Geography. A Global Perspective, Routledge, London.

Ratzel, F 1891, Anthropogeographie. II: Die geographische Verbrietung des Menschen, Stuttgart.

Runge, J 2006, Metody badań w geografii społecznoekonomicznej - elementy metodologii, wybrane narzędzia badawcze [Research methods in social and economic geography - elements of methodology, chosen research tools], Wydawnictwo UŚ, Katowice.

Sokołowski, D 1998, 'Próba określenia względnej wielkości osiedli oraz regionalnych kryteriów miejskości' [An attempt to determine the relative size of settlements and regional urban criteria] in Przekształcenia regionalnych struktur funkcjonalno-przestrzennych [Transformations of the regional functional-spatial structures], ed $\mathrm{J}$ Łoboda, Studia Geograficzne, vol. 69, Wrocław, pp. 111-122.

Sokołowski, D 1999, Zróżnicowanie zbioru małych miast $i$ większych osiedli wiejskich w Polsce w ujęciu koncepcji kontinuum wiejsko-miejskiego [Differences between small towns and larger villages in Poland according to the concept of the rural-urban continuum], Wydawnictwo UMK, Toruń.

Sokołowski, D 2014, 'New towns in Poland', Bulletin of Geography. Socio-economic Series, vol. 23, Toruń, pp. 149-160. 
Sorre, M 1952, Les fondements de la géographie humaine, Paris. Stanny, M, Śliwowska, Z \& Hoffmann, R 2016, 'Miasto - wieś: dychotomia czy continuum? Rozważania osadzone w trzech kontekstach: socjologicznym, ekonomicznym i geograficznym' [Town - village: dichotomy or continuum? Reflections in three contexts: sociological, economic and geographical], Zeszyty Naukowe Wydziału Nauk Ekonomicznych Politechniki Koszalińskiej [Research Bulletins of the Faculty of Economic Sciences of the Koszalin University of Technology], vol. 20, no. 1, pp. 265-279.

Szmytkie, R 2006, 'Stopień rozwoju cech miejskich w małych miastach Polski' [The level of development of urban attributes in small Polish towns], Czasopismo Geograficzne [Geographical Journal], vol. 77, pp. 69-82.

Szmytkie, R \& Krzysztofik, R 2011 'Idea miejskości w Polsce' [The idea of urbanity in Poland] in Przekształcenia regionalnych struktur funkcjonalno-przestrzennych. Zmiany funkcjonalnoprzestrzenne miast $i$ obszarów wiejskich [Transformations of the regional functional-spatial structures. Functionalspatial changes of cities and rural areas], ed B Namyślak, Rozprawy Naukowe IGiRR [Scientific Dissertations of the Institute of Geography and Regional Development], vol. 20, no. 2, Wrocław, pp. 25-40.

Szmytkie, R 2014, 'Metody analizy morfologii i fizjonomii jednostek osadniczych' [Methods of analysis of morphology and physiognomy of settlement units], Rozprawy Naukowe IGiRR [Scientific Dissertations of the Institute of Geography and Regional Development], vol. 35, Wrocław.

Szymańska, W 2009, 'Specjalizacja lokalnej działalności gospodarczej miast Pomorza' [Local specialization of business activity in the towns of Pomerania], Słupskie Prace Geograficzne [Geographical Works of Slupsk], vol. 6, pp. 73-87.

The Act of 8 March 1990 on local self-government. Available from: <https://www.global-regulation.com/translation/ poland/3353885/the-act-of-8-march-1990-on-the-municipalgovernment.html>. [30 April 2018].

The Act of 29 August 2003 on official names of localities and physiographic objects in Poland. Available from: <https:// unstats.un.org/unsd/geoinfo/UNGEGN/docs/NNA/2 Ustawa_o_urzedowych_nazwach_miejscowosci_ENG_ gotowe.pdf>. [30 April 2018].

The Regulation of the Council of Ministers of 9 August 2001 on the procedure to be followed when submitting applications regarding (...) granting municipal status or status of a town, (...) and documents required in these matters.

Vaishar, A, Zapletalova, J \& Novakova, E 2016, 'Between urban and rural. Sustainability of small towns in the Czech Republic', European Countryside, vol. 8, no. 4, pp. 351-372.

Warakomska, K 1992, 'Zagadnienie dostępności w geografii transportu' [The issue of accessibility in transport geography], Przegląd Geograficzny [Polish Geographical Review], vol. 64, pp. 67-76. 